\title{
PERANCANGAN SISTEM PENGKREDITAN PADA SHOWROOM MOBIL ALYA MOTOR
}

\author{
M.Ibnu Safari ${ }^{1}$ \\ Marviyana $^{2}$ \\ Irfan Setiawan ${ }^{3}$

\begin{abstract}
Dosen STMIK Raharja Tangerang ${ }^{1}$, Mahasiswa STMIK Raharja Tangerang ${ }^{2,3}$
Jl. Jendral Sudirman No. 40 Modernland, Tangerang ${ }^{1,2,3}$

e-mail: Ibnu.safari@ raharja.info $^{1}$, Marviyana@ raharja.info $^{2}$, irfan.setiawan@ raharja.info $^{3}$
\end{abstract}

\begin{abstract}
ABSTRAK
Penelitian ini bertujuan untuk menganalisa sistem komputerisasi yang tepat dan akurat. Namun dalam kenyataannya hal tersebut terkadang tidak sesuai dengan keinginan dan harapan yang hendak dicapai, karena terbatasnya sistem komputerisasi sehingga mengalami kelemahan pada aplikasi perhitungan piutang yang digunakan pada Showroom Mobil Alya Motor tersebut. Dengan kurangnya sistem yang terkomputerisasi ini,maka banyak sekali masalah yang terjadi khususnya dalam menyusun laporan penjualan dan menentukan limit kredit pada Showroom Mobil Alya Motor. Antara lain yaitu belum adanya sistem input data laporan kredit sehingga sulit untuk pengambilan keputusan, pembuatan laporan masih belum menghasilkan data yang tepat dan akurat karena sering terjadinya kesalahan dalam penghitungan keluar masuknya uang, dan sering terjadinya selisih/ tidak balance akibatnya proses pembuatan laporan jadi tidak tepat waktu. Menggunakan sistem simulasi perhitungan kredit. Hasil yang didapatkan setelah tahapan uji coba implementasi terhadap system cukup memuaskan karena dapat memenuhi kebutuhan user sekaligus mempermudahkan proses transaksi kredit oleh pelanggan.
\end{abstract}

Kata kunci: Analisa, perancangan, sistem informasi, penjualan, kredit.

\section{ABSTRACT}

This study aims to analyze the computerized system is precise and accurate. But in reality it is sometimes not in accordance with the wishes and expectations to be achieved, due to the limited system is computerized so that experienced weakness in the calculation of accounts receivable applications used on the Motor Car Showroom Alya. With the lack of a computerized system, then a lot of problems that occur, especially in preparing sales reports and determine the credit limits on Alya Motor Car Showroom. Among others, the absence of data input system credit report so it is difficult for decision-making, making the report still has not produced data precise and accurate because of the frequent occurrence of errors in the calculation of entry and exit of money, and often resulted in the difference / no balance consequently the reporting process so imprecise time. Using a simulation system of credit. The results obtained after trial stage of implementation of the system was satisfactory because it can meet the needs of users at once facilitate process credit transactions by customers.

Keywords: Analysis, design, information systems, sales, credit.

Vol 2 No 2 - Agustus 2016 


\section{PENDAHULUAN}

Perkembangan teknologi saat ini merupakan pemicu perusahaan untuk menggali potensi yang dimiliki perusahaan untuk dapat lebih meningkatkan performance perusahaan. Berbagai peluang yang ditemukan di pasaran, sangatlah berguna untuk diubah menjadi potensi-potensi yang dapat dimanfaatkan untuk menghasilkan pendapatan bagi perusahaan. Meskipun pemanfaatan peluang terlihat sebagai suatu hal yang sederhana, namun jika tidak dilakukan dengan kecepatan dan ketepatan perhitungan bisnis yang benar, sebaik apapun peluang yang dimiliki tidak akan mampu dimanfaatkan. Sistem informasi akuntansi merupakan suatu sistem yang terstruktur dalam unit usaha bisnis untuk membantu pelaksanaan kegiatan operasional perusahaan sehari-hari dalam mengatasi permasalahan-permasalahan yang dimulai dari sudut pandang akuntansi yang sesuai dengan kebutuhan perusahaan, membantu manajemen dalam melakukan pengambilan keputusan, dan juga untuk memenuhi pelaksanaan kebijakan dalam perusahaan.

Aktivitas penjualan merupakan salah satu tujuan utama perusahaan setelah memasarkan produk berupa kendaraan mobil. Untuk itu, setiap perusahaan harus mampu mengawasi pelaksanaan penjualan dalam perusahaan itu dengan baik sehingga dari kegiatan penjualan yang terkendali itu, perusahaan dapat memaksimalkan keuntungannya. Selain memiliki sistem penjualan yang baik, perusahaan juga harus memiliki sistem pelayanan piutang yang baik karena banyak perusahaan pemakai barang atau jasa membutuhkan waktu dalam melakukan pembayaran pada saat mereka membeli unit mobil dalam jumlah dan harga yang tidak tinggi. Piutang merupakan unsur penting yang harus diperhatikan oleh perusahaan. Piutang yang terhambat akan mengakibatkan kesulitan bagi perusahaan dalam mengelola atau melaksanakan aktivitas operasional perusahaan sehari-hari. Hal ini disebabkan kurang adanya dana tunai berupa jumlah aktiva lancar yang tersedia secara cukup untuk menunjang keperluan operasi perusahaan.

Showroom Mobil Alya Motor adalah salah satu showroom yang bergerak dalam bidang penjualan dan pengkreditan mobil. Akan tetapi operasional dalam showroom ini masih menggunakan manual dalam perhitungan potongan harga dan perhitungan pengkreditan, sedangkan pengolahan data penjualan dan pengkreditan mobil pada showroom ini masih mencatat di dalam buku dan juga pembuatan laporan masih secara manual.

Hal ini mengakibatkan keterlambatan dalam memberi pelayanan kepada pelanggan, dengan melakukan pembuatan secara manual juga menimbulkan pemborosan waktu dalam membuat laporan perhitungan pengkreditan. Dengan sistem operasional Showroom tersebut resiko akan terjadi kesalahan perhitungan pada saat transaksi dengan pelanggan juga sangat besar.

Melalui masalah-masalah tersebut, maka Showroom Mobil Alya Motor ingin menggunakan suatu aplikasi penghitungan pengkreditan mobil. Agar operasi showroom dapat berkembang dan meminimalkan terjadinya kesalahan.Dari persoalan di atas, mencoba membahas pemecahannya dalam bentuk laporan analisa dengan judul "PERANCANGAN SISTEM PENGKREDITAN PADA SHOWROOM MOBIL ALYA MOTOR”.

\section{IDENTIFIKASI MASALAH}

Berdasarkan permasalahan dari latar belakang tersebut, Showroom Mobil Alya Motor yang masih beroperasi secara manual. Menyebabkan banyak permasalahan yang timbul dan menghambat kegiatan Showroom, oleh karena itu dapat di indentifikasikan beberapa permasalahan yang di hadapi oleh Showroom Mobil Alya Motor antara lain sebagai berikut :

\section{Vol 2 No 2 - Agustus 2016}


1. Sering terjadinya kesalahan dalam proses perhitungan secara manual baik proses perhitungan secara tunai maupun secara kredit.

2. Proses pembuatan laporan secara manual tersebut sering menyebabkan keterlambatan dalam penyerahan laporan kepada pimpinan.

3. Informasi yang dibutuhkan oleh pimpinan tidak akurat karena masih

menggunakan sistem yang manual, sehingga akan menghambat proses dalam

pencarian data dan manipulasi data.

\section{SISTEM PENGKREDITAN}

Menurut Mac Leod mendefinisikan pengertian kredit sebagai berikut (Firdaus dan Ariyanti, 2009:2): Kredit adalah suatu reputasi yang dimiliki seseorang yang memungkinkan ia bisa memperoleh uang, barang-barang atau tenaga kerja, dengan jalan menukarkannya dengan suatu perjanjian untuk membayarnya disuatu waktu yang akan datang.

Dari pengertian-pengertian tersebut diatas, dapat disimpulkan bahwa kredit adalah penyediaan uang berdasarkan ketentuan atau perjanjian tertentu yang telah disepakati oleh pihak Bank dan pihak lain yang mewajibkan pihak peminjam untuk membayar utangnya pada jangka waktu tertentu dengan pemberian bunga.

Unsur-unsur yang terkandung dalam pemberian suatu fasilitas kredit adalah sebagai berikut :

1. Adanya badan atau orang yang memiliki uang, barang atau jasa yang bersedia untuk meminjamkan kepada fihak lain. orang atau barang demikian lazim disebut kreditur,

2. Adanya fihak yang membutuhkan/ meminjam uang, barang atau jasa. Fihak ini lazim disebut debitur,

3. Adanya kepercayaan dari kreditur terhadap debitur,

4. Adanya janji dan kesanggupan membayar dari debitur kepada kreditur,

5. Adanya perbedaan waktu yaitu perbedaan antara saat penyerahan uang, barang atau jasa oleh kreditur dengan pada saat pembayaran kembali dari debitur,

6. Adanya resiko yaitu sebagai akibat dari adanya perbedaan waktu seperti diatas, dimana masa yang akan datang merupakan suatu yang belum pasti, maka kredit itu pada dasarnya mengandung resiko, termasuk penurunan nilai uang karena inflasi dan sebagainya,

7. Adanya bunga yang harus dibayar oleh debitur kepada kreditur (walaupun ada kredit yang tidak berbunga).

\section{SISTEM INFORMASI PENJUALAN DAN PENGKREDITAN}

Menurut Syamsu Iskandar, (2008: 93)Kredit merupakan piutang bagi bank, maka pelunasannya (repayment) merupakan kebijakan yang harus dilakukan oleh debitur terhadap utangnya, sehingga resiko kredit macet dapat dihindarkan".

Menurut Kasmir (2012: 72) mengatakan bahwa: "Dalam bahasa latin kredit disebut credere yang artinya percaya. Maksudnya si pemberi kredit percaya kepada si penerima kredit yang disalurkan pasti akan dikembalikan sesuai perjanjian. Sedangkan bagi si penerima kredit berarti menerima kepercayaan, sehingga mempunyai kewajiban untuk membayar kembali pinjaman tersebut sesuai dengan jangka waktunya".

\section{Tujuan dan Fungsi Kredit}


Menurut Kasmir (2012:88)Pemberian suatu fasilitas kredit mempunyai tujuan tertentu. Tujuan pemberian kredit tersebut tidak akan terlepas dari misi bank tersebut didirikan. Adapun tujuan utama pemberian suatu kredit adalah sebagai berikut:

a. Mencari keuntungan

Yaitu bertujuan untuk memperoleh hasil dari pemberian kredit tersebut. Hasil tersebut terutama dalam bentuk bunga yang diterima oleh bank sebagai balas jasa dan biaya administrasi kredit yang dibebankan kepada nasabah. Keuntungan ini penting untuk kelangsungan hidup bank. Jika bank terus menerus menderita kerugian, maka besar kemungkinan bank tersebut akan dilikuidasi (dibubarkan).

b. Membantu usaha nasabah

Disamping unsur percaya di dalam kredit juga mengandung unsur kesepakatan antara si pemberi kredit dengan si penerima kredit. Kesepakatan ini dituangkan dalam suatu perjanjian di mana masing-masing pihak menandatangani hak dan kewajibannya masing-masing.

\section{DEFINISI PENJUALAN KREDIT}

Defenisi penjualan kredit menurut Mulyadi (2007;220) "Penjualan kredit dilaksanakan oleh perusahaan dengan cara mengirimkan barang sesuai dengan order yang diterima dari pembeli dan untuk jangka waktu tertentu perusahaan mempunyai tagihan kepada pembeli tersebut".

Sesuai dengan penjelasan diatas, dapat ditarik kesimpulan penjualan kredit yaitu transaksi penjualan yang dilakukan tetapi pembayarannya menggunakan jangka waktu tertentu sesuai kesepakatan bersama. Untuk mendapatkan pengawasan intern yang baik pada penjualan kredit perlu disusun prosedur tertentu yang menggambarkan arus dokumen dan tata cara pencatatan penjualan kredit yang harus diperhatikan adalah :

1) Surat Order Pengiriman

Dokumen ini merupakan lembar pertama surat order pengiriman yang memberikan otorisasi kepada kepala bagian pengiriman untuk mengirimkan jenis barang dan jumlah spesifikasi seperti yang tertera diatas dokumen tersebut. Dalam hal pemberian surat order pengiriman dilakukan oleh bagian gudang dan memberikan otorisasi kepada bagian pengiriman barang.

2) Faktur Penjualan

Dokumen ini merupakan lembar pertama yang dikirimkan pada pelanggan. Jumlah lembar faktur yang dkirim kepada pelanggan adalah tergantung dari permintaan pelanggan.

Catatan akuntansi yang digunakan dalam prosedur penjualan kredit adalah:

1) Jurnal Penjualan

Catatan akuntansi ini digunakan untuk mencatat transaksi penjualan kredit. Jurnal penjualan digunakan untuk mencatat dan meringkas data penjualan. Jika perusahaan menjual berbagai macam produk dan manajemen memerlukan informasi penjualan tiap jenis produk yang dijualnya selama jangka waktu tertentu dalam jurnal penjualan disediakan kolom - kolom untuk mencatat penjualan menurut produk tersebut.

Kas $\quad \mathrm{xxx}$

Piutang Usaha $x x x$

Harga Pokok Penjualan $\quad x x x$

Persediaan Barang Dagang $\quad$ xx

Vol 2 No 2 - Agustus 2016 
2) Kartu Piutang

Catatan akuntansi ini merupakan buku pembantu yang berisi rincian mutasi piutang perusahaan kepada tiap - tiap debiturnya. Dalam metode pencatatan piutang tertentu, buku piutang ini tidak diselenggarakan dan digantikan fungsinya dengan arsip faktur penjualan menurut abjad.

3) Kartu Persediaan

Catatan akuntansi ini merupakan buku pembantu yang berisi tentang rincian mutasi tiap jenis persediaan.

\section{ANALISA SISTEM YANG BERJALAN}

Analisa sistem adalah penelitian atas sistem yang telah ada dengan tujuan untuk merancang sistem yang baru ,Tugas utama analisa sistem dalam tahap ini adalah menemukan kelemahankelemahan dari sistem yang berjalan sehingga dapat diusulkan perbaikannya.

Analisa sistem informasi ini merupakan tahap penganalisaan terhadap sistem yang sedang berjalan pada showroom ALYA Motor yaitu tentang Penjualan dan Pengkreditan Mobil. Penganalisaan terdiri dari analisa sistem yang sedang berjalan, analisa data, analisa dokumen, analisa kebutuhan sistem.

\section{A. Analisa Sistem yang Sedang Berjalan}

Untuk memenuhi salah satu tujuan penelitian yaitu memberikan alternatif solusi kepada perusahaan terhadap upaya pengembangan sistem yang sudah ada menjadi sebuah sistem yang jauh lebih efektif dan efisien maka perlu adanya analisa terhadap sistem yang sedang berjalan sebagai acuan untuk tahap selanjutnya.

Berdasarkan pengamatan analisa yang dilakukan pada showroom ALYA Motor [ perusahaan ini masih menggunakan perhitungan secara manual ]

sehingga masih banyak terdapat kekurangan yang berpengaruh terhadap efisien dan efektifitas sistem kinerja perusahaan sebagaimana yang telah dikemukakan dalam identifikasi masalah.

1. Prosedur Penjualan Mobil Secara Tunai yang Sedang Berjalan

Dibawah ini adalah prosedur penjualan mobil secara tunai yang sedang berjalan pada Showroom ALYA Mobil sebagai berikut:

a) Pelanggan akan memberikan form pesanan kepada bagian penjualan.

b) Bagian penjualan akan mengecek form penjualan tersebut.

c) Apabila pesanan yang diinginkan tersedia maka bagian penjualan akan membuat surat jalan.

d) Dari surat jalan tersebut bagian penjualan akan mencetak kwitansi dan diserahkan ke pelanggan.

e) Setelah membuat kwitansi, bagian penjualan akan membuat laporan penjualan dan diserahkan kepada pimpinan.

f) Salah satu rangkap dari laporan penjualan tersebut akan diserahkan kepada bagian gudang.

g) Bagian gudang akan mengecek persediaan dan membuat laporan persediaan.

h) Laporan persediaan yang dibuat oleh bagian gudang akan diserahkan kepada pimpinan.

\section{Use Case Diagram Sistem Yang Berjalan}




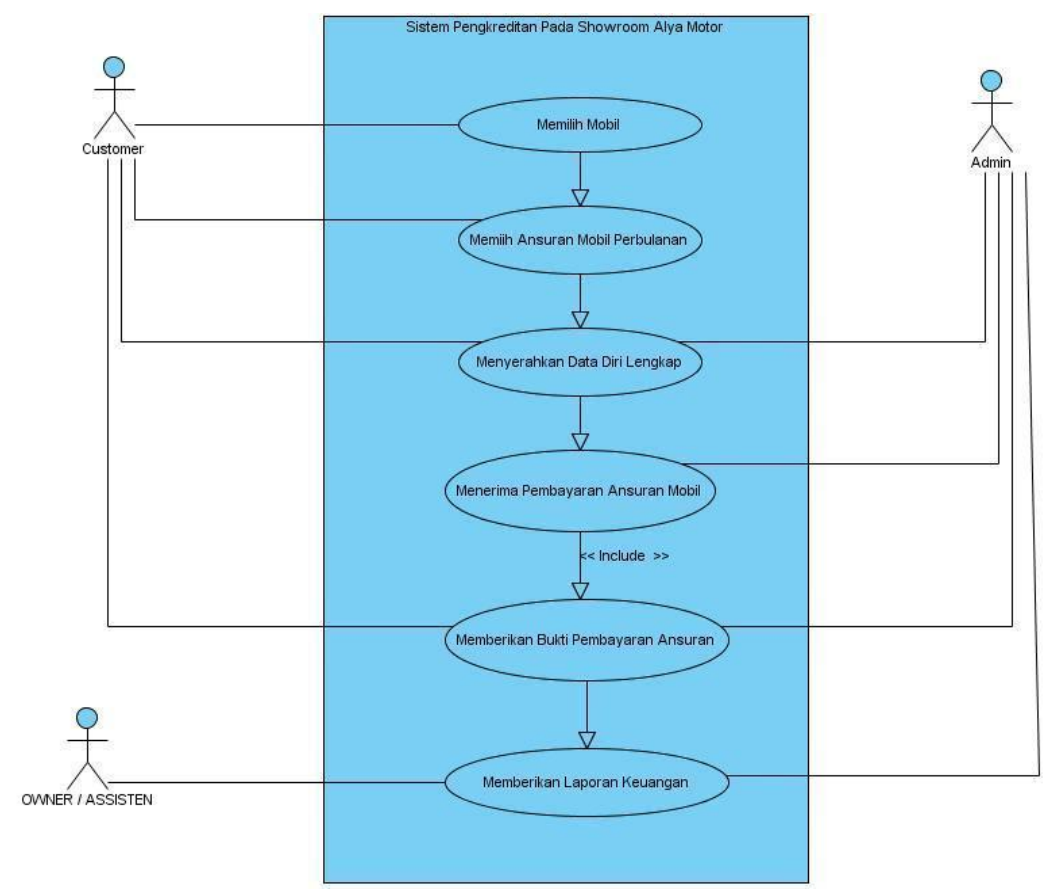

Gambar 1.1 Use Case :Diagram Sistem Pengkreditan Alya Motor

\section{Prosedur Penjualan Mobil Secara Kredit yang Sedang Berjalan}

Dibawah ini adalah prosedur penjualan mobil secara kredit yang sedang berjalan di Showroom mobil ALYA Motor :

a) Bagian pelanggan menyerahkan fotocopy KTP kepada bagian penjualan.

b) Bagian penjualan melakukan pengecekan KTP tersebut.Apabila pelanggan tersebut berusia dibawah 21 tahun maka pengajuan kredit akan ditolak, sedangkan apabila pelanggan berusia diatas 21 tahun maka pengajuan kredit akan diproses.

c) Setelah pengajuan kredit disetujui, maka bagian penjualan akan melakukan pencatatan data pelanggan dan memberikan form kredit kepada pelanggan.

d) Form kredit tersebut akan diisi oleh pelanggan dan diserahkan kembali kepada bagian penjualan, dimana bagian penjualan akan menyerahkan form tersebut kepada Bank Sinarmas.

e) Bank sinarmas akan melakukan pengecekan terhadap form kredit tersebut dan mengambil keputusan apakah pengajuan kredit ditolak atau diterima.

f) Apabila diterima maka bagian Bank Sinarmas akan melakukan proses pembuatan surat keterangan pembelian dan tagihan yang akan diserahkan kepada pelanggan.

g) Dari surat keterangan tersebut, Bank Sinarmas akan melakukan proses pembuatan laporan penjualan.

h) Laporan penjualan tersebut akan diserahkan kepada bagian penjualan dan bagian penjualan akan membuat surat jalan.

i) Surat jalan yang dibuat oleh bagian penjualan akan diserahkan kepada bagian gudang dan bagian gudang akan membuat laporan persediaan. 
j) Laporan penjualan dan persediaan akan diserahkan kepada pimpinan.

\section{B. Analisa Kelemahan Sistem}

Dari hasil analisa sistem yang sedang berjalan, sistem pengolahan data penjualan mobil secara tunai maupun kredit pada Showroom ALYA Mobil masih kurang efektif dan efisiensi. Sistem tersebut masih memiliki kelemahan dan keterbatasan, diantaranya :

1. Proses pencarian data membutuhkan waktu yang lama.

2. Dapat terjadi penduplikatan data.

3. Masih belum menggunakan sebuah aplikasi yang mendukung sehingga dalam mencetak, menyimpan dan memproses semua data penjualan masih kurang efektif dan efisien sehingga terjadi banyak kesalahan dalam berbagai faktor.

4. Proses pencatatan data pelanggan, data mobil second dan penjualan dibuku, sehingga data sering rusak, pencatatan tidak jelas, tercecer bahkan hilang.

\section{Analisa Kebutuhan Sistem}

Dalam sistem informasi penjualan dan pengkreditan yang dikomputerisasikan diperlukan beberapa komponen pekerjaan untuk mendukung sistem yang berjalan, diantaranya :

1. Sistem yang dapat mempercepat pekerjaan dan tidak membutuhkan waktu yang lama.

2. Dapat menjamin keamanan data yang disimpan dan penyimpanan file tidak dilakukan secara terpisah.

\section{Sequence Diagram Sistem Yang Berjalan}

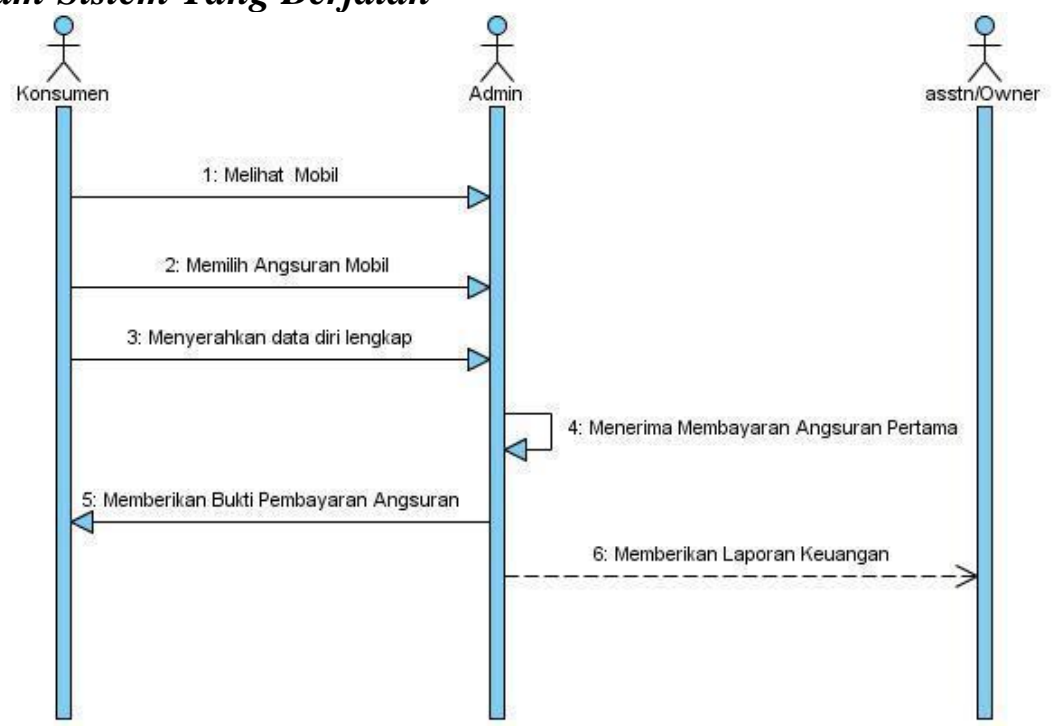

Gambar 1.2 Sequence Diagram Pengkreditan Pada Alya Motor

Berdasarkan gambar Sequence Diagram Pembuatan Laporan Penjualan Pada Showroom alya motor yang berjalan diatas terdapat:

a. $\quad 3$ actor yang melakukan kegiatan, yaitu Konsumen, bagian Karyawan, Admin \& Assisten / Owner.

b. 1 lifeline, yaitu Laporan Keuangan. 
c. 6 message yang memuat informasi-informasi tentang aktivitas yang terjadi yaitu,Memberikan Konsumen pelayanan terbaik untuk melihat spesifikasi unit mobil, Memberikan Harga sesuai dengan kualitas mobil, memberi daftar harga perunit mobil dengan rincinan angsurans perbulannya, Penawarkan pembayaran secara cash atau kredit oleh konsumen,Konsumen wajib menyerahkan data diri pribadi dengan lengkap, Menerima Pembayaran Pertama yang sudah di sepakati bersama, Memberikan Bukti pembayaran beserta tanda bukti pembayaran, Memberikan laporan keuangan.

\section{SASARAN SISTEM INFORMASI PENJUALAN DAN PENGKREDITAN}

Sasaran secara umum dari sistem informasi penjualan dan pengkreditan adalah:

- Untuk mencatat pesanan pelanggan secara cepat dan tepat.

- Untuk memverifikasi bahwa pelanggan layak mendapatkan kredit.

- Untuk mengirimkan unit pada tanggal telah disetujui.

- Untuk melakukan penagihan atas produk atau jasa secara tepat pada waktunya dan dengan prosedur yang benar.

- Untuk mencatat dan mengklasfikasikan penerimaan kas secara cepat dan tepat.

\section{PROSES BISNIS PENJUALAN DAN PENGKREDITAN}

Penjualan di SHOWROM MOBIL ALYA MOTOR dilakukan secara cash dan kredit. Unit mobil jadi yang dijual dengan sistem cash,kredit dan Pelanggan yang ingin memesan unit bisa dilakukan secara langsung.Costumer bisa datang langsung ke showroom alya melihat seluruh stok unit mobil yang tersedia sambil mengecekan fisik mobil yang diinginkan. Jika costumer membeli dengan cara cash sales penjualan membuat nota pembelian dan pengurusan surat jalan kendaraan, surat penyerahan BPKB dan surat jual beli kendaraan. Dan jika costumer membeli secara kredit.akan terjadinya proses penawaran unit mobil yang ingin dibeli secara system pengreditan yang telah di tentukan oleh finance setelah itu akan pernyerahan data costumer yang di tentukan persyaratan pada pihak showroom dan finance.

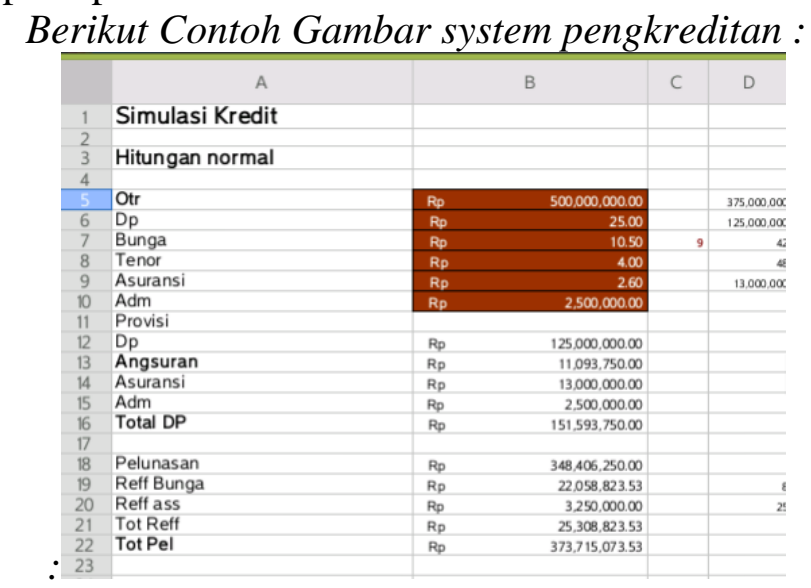

Gambar 1.3 pengkreditan Showroom alya motor

Berdasarkan gambar Simulasi penjualan kredit Pada Showroom alya motor yang berjalan diatas terdapat :

1. OTR : harga yang tertera pada harga mobil tersebut

2. DP : tanda jadi yang harus dibayar oleh konsumen dengan $25 \%$

3. Bunga : hasil dari pokok hutang 
4. Tenor : masa pelunasan pinjaman dinyatakan dalam hitungan tahun

5. Asuransi : perlindungan sebagai keselamatan mobil tersebut

6. Admin : pajak untuk pengajuan pengkreditan

7. Provisi : biaya lain-lain yang tidak perlu digunakan

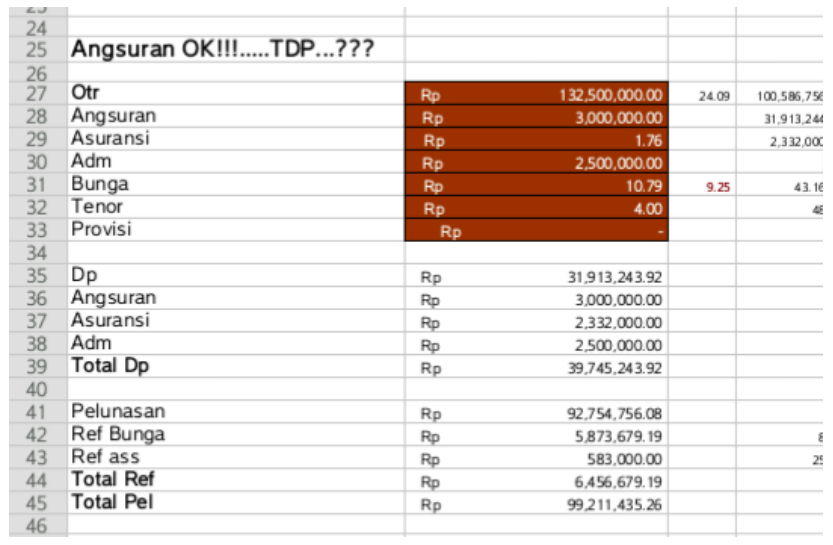

Gambar 1.4 Angsuran pengkreditan Pada showroom alya motor

Contoh gambar jika costumers telah setuju dengan perhitungan kredit yang akan di bayar setiap bulannya.

\section{a. Landasan Teori}

\section{Landasan Teori dan Literature Review}

Menurut Sutarman (2012:13), "sistem adalah kumpulan elemen yang saling berhubungan dan saling berinteraksi dalam satu kesatuan untuk menjalankan suatu proses pencapaian suatu tujuan utama".

Menurut McLeod dalam Yakub (2012:1) "Sistem adalah sekelompok elemen - elemen yang terintegrasi dengan tujuan yang sama untuk mencapai tujuan". Dari kedua pendapat tersebut dapat disimpulkan bahwa sistem adalah kumpulan elemen yang terintegrasi untuk mencapai satu tujuan utama.

a. Tujuan Sistem (Goal)

Tujuan ini menjadi motivasi yang mengarahkan pada sistem, karena tanpa tujuan yang jelas sistem menjadi tak terarah dan tak terkendali.

b. Masukan (input)

Masukan (input) sistem adalah segala sesuatu yang masuk kedalam sistem dan selanjutnya menjadi bahan yang diproses. Masukan dapat berupa hal-hal yang berwujud (terlihat secara fisik) maupun yang tidak tampak.

c. Proses (process)

Proses (process) merupakan bagian yang melakukan perubahan atau transformasi dari masukan menjadi keluaran yang berguna dan lebih bernilai, misalnya berupa informasi dan produk, tetapi juga berupa hal-hal yang tidal berguna.

Penghubung Sistem (interface) 
Penghubung sistem (interface) merupakan media yang menghubungkan sistem yang membentuk satu kesatuan.

Keluaran (output)

Keluaran (output) merupakan hasil dari pemrosesan sistem dan keluaran dapat menjadi masukan untuk subsistem lain.

\section{b. Studi Pustaka Literature Review}

Studi pustaka sebagai salah satu dari penerapan metode penelitian yang dilakukan, diantaranya sebagai berikut :

1. Penelitian yang telah dijalankan oleh Siti Maesaroh tahun 2015 yang berjudul "Perancangan Sistem Informasi Cash Flow Penerimaan dan Pengeluaran Kuangan CV. Karya Dwi Putri”. Sistem yang berjalan saat ini belum mampu menyediakan informasi yang dibutuhkan dengan cepat dan akurat karena masih menggunakan sistem manual dengan cara pembuatan laporan dengan menggunakan Microsoft Excel. Sehingga dalam penelitian ini menghasilkan sistem keuangan cash flow terkomputerisasi menggunakan bahasa pemograman PHP, dan menggunakan database MySQL. Visual Basic sebagai interface untuk user. Agar laporan cash flow penerimaan dan pengeluaran keuangan berjalan efektif dan efesien

2. Penelitian yang telah dijalankan oleh Ratih Kumalasari tahun 2015 yang berjudul "Sistem Informasi Laporan Arus Kas Pada Studio Musik 99”, dimana sistem pengolahan laporan masih manual, dalam artian masih pada catatan manual didalam sebuah buku besar yang sewaktu - waktu dapat hilang dan tidak tercatat dengan rapih. Sistem laporan arus kas yang efektif dan efisien dilakukan dengan sistem komputerisasi, maka dalam penelitian ini penulis membuat sistem terkomputerisasi berbasis web yang dirancang dengan menggunakan notepad ++ serta terhubung ke dalam xampp sebagai penyimpanan database.

3. Penelitian yang telah dijalankan oleh Maulida pada tahun 2014 yang berjudul "Perancangan Sistem Informasi Laporan Keuangan Penjualan Pada PT. Putera Pasar Baru", Sistem informasi laporan keuangan pada PT. Putera Pasar Baru untuk saat ini sudah menggunakan komputer tetapi program yang digunakan belum memadai atau masih menggunakan cara manual, yaitu data yang penjualan yang sudah masuk ditulis dibuku besar, dan pengumpulan datanya masih dilakukan secara manual sehingga sering terjadinya kehilangan data. Selanjutnya dibuatlah program dengan bahasa pemrograman PHP, App Serv sebagai pendukung aplikasi yang digunakan sebagai web server dan juga menggunakan MySQL sebagai database yang dibangun, dan sebagai media tampilan menggunakan Dreamweaver. Sehingga dapat menyelesaikan permasalahan yang ada.

4. Penelitian yang dijalankan oleh Arif Kunto Wibisono tahun 2011 yang berjudul "Analisis dan Pembuatan Aplikasi Akuntansi Berbasis Web Pada IIUC". Dalam penelitian ini penulis membuat aplikasi berbasis web dengan menggunakan bahasa pemrograman PHP dan database MySQL, web server yang digunakan adalah Apache, dan menggunakan jQuery untuk membuat aplikasi lebih interaktif. Hasil dari penelitian ini adalah aplikasi akuntansi yang dapat di akses secara online sehingga dapat memudahkan bagian keuangan dalam memasukkan transaksi-transaksi keuangan yang berlangsung serta memberi kemudahan bagi para manager untuk melihat keadaan keuangan di International Islamic University College (IIUC) sebagai informasi untuk mangambil keputusan.

Vol 2 No 2 - Agustus 2016 
Berdasarkan literature-literature review di atas, sehingga penelitian ini termasuk ke dalam jenis analisa yang sedang di hadapi.

\section{KESIMPULAN}

Semua tahapan dari penelitian ini sudah dijalankan sampai kepada implementasi sistem, berdasarkan apa yang Dijalani merupakaan ringkasan yang ditarik dari pembahasan terhadap perancangan sistem perangkat lunak yang dibuat. dari hasil pengujian penggunaan pada perangkat lunak simulasi kredit yang dirancang sebagai bahan pertimbangan dalam upaya peningkatan daya kerja Showroom MOBIL ALYA MOTOR dalam menjalankan usahanya dibidang penjualan mobil.

Berdasarkan hasil analisa, perancangan dan pembuatan perangkat lunak yang dibuat untuk Showroom Alya motor, menghasilkan kesimpulan bahwa :

1. Dapat membantu kelancaran, kecepatan dan efisiensi kerja dibagian pengkreditan yang menangani kesalahan perhitungan data.

2. Dapat mengurangi kesalahan yang disebabkan oleh faktor kelalaian manusia yang diakibatkan oleh banyaknya file-file yang tersimpan manual.

3. Membantu menghitung pengkreditan dengan akurat, sehingga dapat memberikan informasi yang tepat dan benar.

\section{DAFTAR PUSTAKA}

[1].Huda, Syaiful.2014. Sistem Informasi Keuangan Berbasis Desktop dengan Java Standard Edition \& MYSQL di Sekolah Tinggi Teknologi Nurul Jadid Paiton Probolinggo. Diambil dari: http://www.academia.edu/8328077/

SISTEMINFORMASI_KEUANGAN_BERBASIS_DESKTOP_DENGAN_JAVA_STANDARD _EDITION_and_MYSQL_DI_SEKOLAH_TINGGI_TEKNOLOGI_NURUL_JADID_PAITO N_PROBOLINGGO.

[2].Kumalasari, Ratih.2015.Sistem Informasi Laporan Arus Kas Pada Studio Musik 99.Tangerang.

[3].Kurniawan, Erick dan Antonius Rachmat.2010.Teknologi Informasi Dan Komunikasi.Jakarta:Pusat Perbukuan Kementerian Pendidikan Nasional.

[4].Maesaroh, Siti.2014.Analisa Sistem Informasi Cash Flow Penerimaan dan Pengeluaran Keuangan CV. Karya Dwi Putri.Tangerang.

[5].Nugroho, Andi.2010.Analisis Perancangan Sistem Teknologi Informasi Dengan dMetodologi Berorientasi Object.Bandung:Informatika 